\title{
Anti-oxidant and Anti-melanogenic Activity of the Methanol Extract of Pine Cone
}

\author{
Ah Reum Lee ${ }^{1}$, Seong-Soo Roh ${ }^{1}$, Eun-Sook Lee ${ }^{2}$, Yu-Hong Min ${ }^{3 *}$ \\ ${ }^{1}$ College of Korean Medicine, Daegu Haany University, Daegu, Korea \\ ${ }^{2}$ Department of Herbal Skin Care \& Cosmetology, Daegu Haany University, Gyeongsan-si, Gyeongsangbuk-do, Korea \\ ${ }^{3}$ Department of Beauty Care, Daegu Haany University, Gyeongsan-si, Gyeongsangbuk-do, Korea
}

\author{
"Corresponding author: Yu-Hong Min, \\ Department of Beauty Care, Daegu Haany \\ University, 1 Haanydae-ro, Gyeongsan-si, \\ Gyeongsangbuk-do 38610, Korea \\ Tel.: +82538191587 \\ Fax: +82 538191572 \\ Email:yhmin@dhu.ac.kr
}

Received June 8, 2016

Revised August 1, 2016

Accepted August 24, 2016

Published September 30, 2016

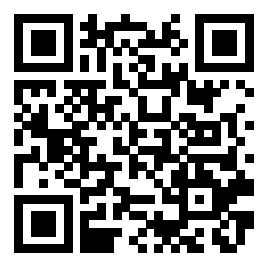

\begin{abstract}
Purpose: This study was conducted to evaluate anti-oxidant and anti-melanogenic activities of pine cone extract from Pinus densiflora. Methods: Pine cone extract used in this experiment was extracted with methanol at room temperature for $24 \mathrm{~h}$. Anti-oxidant activities were measured by 2,2-Diphenyl-1-picrylhydrazyl (DPPH) radical scavenging assay and nitro blue tetrazolium chloride (NBT) assay. Moreover, the inhibitory effects of pine cone methanol extract on tyrosinase and melanin synthesis in murine B16-F10 melanoma cells were studied. In addition, cell viability was investigated by MTT assay. Results: The results showed that the pine cone methanol extract strongly reduced the DPPH free radical activity $\left(\mathrm{IC}_{50}=9.57 \pm 1.24 \mu \mathrm{g} / \mathrm{mL}\right)$. However, its activity was lower than the activity of L-ascorbic acid (positive control, $I_{50}=1.28 \pm 0.03 \mu \mathrm{g} / \mathrm{mL}$ ). In NBT assay, the pine cone methanol extract exhibited more superoxide anion radical scavenging activity $\left(\mathrm{IC}_{50}=3.33 \pm 0.28 \mu \mathrm{g} / \mathrm{mL}\right)$, compared with L-ascorbic acid $\left(\mathrm{IC}_{50}=73.25 \pm 1.02 \mu \mathrm{g} / \mathrm{mL}\right)$. When treated with 3,4-Dihydroxy-L-phenylalanine (L-DOPA) as the substrate of tyrosinase, the extract inhibited the tyrosinase activity with an $\mathrm{IC}_{50}$ value of $106.15 \pm 1.69 \mu \mathrm{g} / \mathrm{mL}$, lower effect than that of kojic acid $\left(\mathrm{IC}_{50}=3.12 \pm 0.68 \mu \mathrm{g} / \mathrm{mL}\right)$. In murine B16-F10 cells, the pine cone methanol extract significantly suppressed melanogenesis in a concentration-dependent manner without cytotoxicity. Conclusion: The results indicated that pine cone extract could be potentially valuable as a new potent depigmentation agent.
\end{abstract}

Keywords: Pine cone, Methanol extract, Anti-oxidant activity, Anti-melanogenic activity, Cytotoxicity

\section{Introduction}

사람의 피부색은 melanin, hemoglobin, carotene 및 각질층 의 두께 등에 의해 결정되는데, 그 중 가장 주된 요인은 melanin 으로 표피의 기저층에 존재하는 melanocyte에서 합성이 된다. Melanocyte에서 tyrosine은 tyrosinase에 의해 무수한 산화반응 을 거쳐 melanin을 만드는데, 이렇게 생성된 melanin은 자외선 을 흡수하거나 산란시켜 피부가 상하는 것을 막아준다. 그러나, 과도한 melanin 생성은 피부 색소침착의 원인이 되는데, 미백제 는 자외선을 차단하거나 또는 기존의 침착된 melanin을 옅게 하 여 기미나 주근깨의 생성을 억제함으로써 피부의 미백에 도움을 주는 기능을 한다. 미백제로 널리 사용되는 물질은 tyrosinase의
활성을 억제하는 것으로 알려진 kojic acid, arbutin, 감초추출 물, 닥나무추출물 등이 있고, melanin 합성을 차단하는 vitamin C, glutathione, coenzyme $\mathrm{Q}_{10}$ 등이 사용되고 있다(Lee et al., 2007).

대사과정 중 발생되는 슈퍼옥사이드 음이온 라디칼(superoxide anion radical), 과산화수소(hydrogen peroxide) 등과 같은 산소 의 대사산물을 일반적으로 활성산소종(reactive oxygen species, $\mathrm{ROS})$ 이라 하며 우리 인체 내에서의 비만 및 각종 피부질환의 원 인이 된다(Shon et al., 2016). ROS는 matrix metalloproteinase (MMP)를 생성하여 콜라겐의 비정상적인 교차결합 유발 및 손 상을 일으켜 피부 노화를 촉진시킨다. 항산화제는 이러한 ROS 의 산화반응을 지연시키거나 억제시킬 수 있는 물질로서 대표적으 
로 superoxide dismutase (SOD), catalase, $\mathrm{L}$-ascorbic acid, $\alpha$ -tocopherol, flavonoid 등이 있다(Kim et al., 2015).

소나무(Pinus densiflora)는 낮은 산에서 자라는 상록성 침엽 교목으로 키는 30-40 m로 자라고, 수피가 벗겨지면 적갈색이 되 기 때문에 적송이라고 부른다. 우리나라를 비롯하여 일본, 중국 등지에서 분포되어 있으며 솔잎, 송진, 송목피 등은 구황식품으로 도 널리 식용되어 왔다(Jang et al., 2016)

솔방울은 소나무의 방울열매로 송구(松球), 송실(松實)이라고도 부르며, 기존 연구 결과에 따르면 솔방울의 terpenoid 성분을 분 석한 결과, monoterpene인 $\beta$-phellandrene이 가장 많이 함유 되어 있었고(Choi \& Hwang, 1994), in vitro 실험에서는 lignin 성 분이 항산화 효과가 뛰어난 것으로 나타났을 뿐 아니라(Satoh et al., 1999), in vivo 실험에서 항암 및 항균효과가 뛰어난 것으로 보 고되었다(Sakagami et al., 1991).

이처럼 솔방울에 대한 연구가 활발히 이루어 지고 있으나, 솔 방울 추출물에 대한 미용학적 연구는 미비한 실정이다. 따라 서 본 연구에서는 솔방울 메탄올(methanol, $\mathrm{MeOH})$ 추출물의 tyrosinase 억제 및 항산화 효과를 측정하여, 피부미용적 효능을 규명하고 항산화 및 미백용 소재로서의 활용가능성을 평가하고자 하였다.

\section{Methods}

\section{1. 실험재료}

본 실험에 사용된 2,2-Diphenyl-1-picrylhydrazyl (DPPH), Xanthine, 4-Nitro blue tetrazolium chloride (NBT), Xanthine oxidase from bovine milk, 3,4-Dihydroxy-L-phenylalanine (L-DOPA), Thiazolyl blue tetrazolium bromide (MTT), L-ascorbic acid, Tyrosinase from mushroom, $\alpha$-Melanocyte stimulating hormone $(\alpha-\mathrm{MSH})$, Melanin은 Sigma-Aldrich (USA)에서 구입하여 사용하였고, Potassium phosphate dibasic, Potassium phosphate monobasic, Sodium carbonate 는 OCI Company (Korea)에서 구입하였으며, Dimethyl sulfoxide (DMSO)는 Amresco (USA)에서 구입하였다. Fetal Bovine Serum (FBS), Dulbecco's Modified Eagle Medium (DMEM)은 Gibco (USA)에서 구입하였다. 마우스 melanoma인 B16-F10 및 인간피부에서 유래한 섬유아세포인 CCD-1064SK 의 세포주는 American Type Culture Collection (ATCC; USA) 에서 구입하였다.

\section{2. 시료준비}

본 실험에서 사용한 솔방울은 대한민국 경상북도 경산시에서 채취하여 실험의 재료로 사용하였다. 솔방울 $25 \mathrm{~g}$ 을 파쇄하여 메
탄올 $500 \mathrm{~mL}$ 에 넣고 상온에서 $24 \mathrm{~h}$ 동안 추출하였으며, 추출 액을 Whatman NO.2 여과지(GE healthcare, UK)로 여과하여 evaporator (Eyela, Japan)로 감압 농축한 후, 동결건조하여 냉장실 에 보관하면서 본 실험의 시료로 사용하였다. 솔방울 $25 \mathrm{~g}$ 으로 얻어 진 메탄올 추출물의 양은 $1 \mathrm{~g}$ 으로써 수득률(yield)은 $4 \%(\mathrm{w} / \mathrm{w})$ 이었다.

\section{3. 전자공여능 측정}

전자공여능(electron donating ability)은 Blois (1958) 방법 에 의한 DPPH free radical 소거법으로 측정되었다. $\mathrm{DPPH}$ 는 시 료 중에 포함된 항산화 물질의 양을 측정하는데 사용되는 대표적 인 시약이다. 보라색의 free radical인 DPPH용액이 시료 중에 있 는 항산화 물질과 결합하여 환원이 되면 용액은 투명하게 변한 다. 일정농도의 시료 $0.75 \mathrm{~mL}$ 과 $0.3 \mathrm{mM} \mathrm{DPPH}$ 용액(dissolved in methanol)을 $0.3 \mathrm{~mL}$ 넣고 혼합한 후, 실온에서 $30 \mathrm{~min}$ 동 안 반응시켰다. 이 반응액을 UV spectrophotometer (UV1800; Shimadzu, Japan)를 사용하여 $517 \mathrm{~nm}$ 에서 흡광도를 사용하여 측정한 후, 전자공여능은 아래의 식에 의해 계산하여 산출하였다. 시료를 첨가하지 않은 대조군의 흡광도를 $50 \%$ 감소시키는데, 필 요한 시료의 양을 $\mathrm{IC}_{50}$ (50\% inhibition concentration)으로 하여 나타내었으며 대조군으로는 L-ascorbic acid를 사용하였다.

Radical scavenging activity $(\%)=\left\{\left(\mathrm{OD}_{\text {control }}-\mathrm{OD}_{\text {sample }}\right) / \mathrm{OD}_{\text {control }}\right\} \times 100$ $\mathrm{OD}_{\text {control }}$ : 시료가 들어가지 않은 경우(대조군) 흡광도

$\mathrm{OD}_{\text {sample }}$ : 시료가 들어간 경우 흡광도

\section{4. 활성산소 소거능 측정}

Xanthine이 xanthine oxidase에 의해 산화되어 uric acid 가 될 때 활성산소도 함께 발생하는데, 이 활성산소는 NBT 를 formazan형태로 환원시킨다. 이 formazan의 흡광도를 UV spectrophotometer를 사용하여 $560 \mathrm{~nm}$ 에서 측정하였다 (Aruoma et al., 1993). 0.1 M potassium phosphate buffer (pH 7.8)를 $690 \mu \mathrm{L}$ 그리고 $10 \mathrm{mM}$ xanthine, $5 \mathrm{mM} \mathrm{NBT}$ 용액을 각 각 $100 \mu \mathrm{L}$ 씩 넣고, 일정농도의 시료를 $10 \mu \mathrm{L}$ 씩 첨가한 후, 0.3 units $/ \mathrm{mL}$ xanthine oxidase 용액을 $100 \mu \mathrm{L}$ 씩 넣어 반응을 시 작한다. 상온에서 $10 \mathrm{~min}$ 동안 방치한 후 $560 \mathrm{~nm}$ 에서 흡광도를 측정하여 활성산소 소거능을 계산하였다. Xanthine oxidase 용 액대신 $0.1 \mathrm{M}$ potassium phosphate buffer (pH 7.8)를 넣은 것 을 blank로 하였고, 대조군의 흡광도를 $50 \%$ 감소시키는데 필 요한 시료의 양을 $\mathrm{IC}_{50}$ 으로 하여 나타내었으며, 대조군으로는 $\mathrm{L}$-ascorbic acid를 사용하였다.

Superoxide scavenging activity $(\%)=\left\{\left(\mathrm{OD}_{\text {contuol }}-\mathrm{OD}_{\text {sample }}\right) / \mathrm{OD}_{\text {contaol }}\right\} \times 100$ $\mathrm{OD}_{\text {control }}$ : 시료가 들어가지 않은 경우(대조군) 흡광도

$\mathrm{OD}_{\text {sample }}$ : 시료가 들어간 경우 흡광도 


\section{Tyrosinase 활성 억제 효과}

솔방울 메탄올 추출물의 tyrosinase 활성 억제 정도를 다음 과 같이 측정하였다(Nerya et al., 2004). 96-well microplate의 각 well에 시료 및 $0.1 \mathrm{M}$ potassium phosphate buffer (pH 6.8) 를 넣어 최종 부피가 $70 \mu \mathrm{L}$ 가 되도록 하였다. 이 때 시료의 비극 성 성분을 녹이기 위해 $\mathrm{DMSO}$ 를 $5 \%$ 가 되도록 넣었으며 이는 실 험에 영향을 미치지 않는다는 사실을 사전 실험을 통하여 확인 하였다. 다음으로 0.1 M potassium phosphate buffer (pH 6.8) 에 tyrosinase를 333 units $/ \mathrm{mL}$ 의 농도로 녹인 용액을 $30 \mu \mathrm{L}$ 씩 넣은 후 상온에서 $5 \mathrm{~min}$ 동안 방치하였으며, 0.1 M potassium phosphate buffer (pH 6.8)에 $12 \mathrm{mM}$ 의 농도로 녹인 L-DOPA 용액을 $100 \mu \mathrm{L}$ 씩 가하였다. 이 반응액을 microplate reader (Infinite M200; Tecan, Switzerland)를 사용하여 $492 \mathrm{~nm}$ 에서 2 $\mathrm{min}$ 동안 흡광도를 측정한 후, tyrosinase 활성 저해율을 산출하 였다.

\section{Melanin 생합성 억제 효과}

솔방울 메탄올 추출물과 kojic acid의 melanin 생합성 억 제효과는 다음과 같이 측정하였다(Choi et al., 2010). 마우스 melanin 형성세포인 B16-F10세포를 충분히 배양 한 후, 6-well plate에 $2 \times 10^{5}$ cells/well의 농도로 분주하고, 세포가 바닥에 잘 부착할 수 있게 $37^{\circ} \mathrm{C}, 5 \% \mathrm{CO}_{2}$ 에서 $24 \mathrm{~h}$ 배양하였다. 시료 를 농도 별로 희석하여 $10 \% \mathrm{FBS}$ 가 포함된 DMEM을 혼합한 후, melanin 생성을 촉진하는 $\alpha-\mathrm{MSH}$ 를 $10 \mathrm{nM}$ 가해주었다. 시료를 이틀 간 처리한 후, 배지를 제거하고 phosphate buffered saline (PBS)로 2번 세척한 뒤, lysis buffer (20 mM Tris, 0.1\% Triton $\mathrm{X}-100, \mathrm{pH}$ 7.6) $0.5 \mathrm{~mL}$ 을 취하여 $4{ }^{\circ} \mathrm{C}$ 에서 $1 \mathrm{~h}$ 방치하였다. 그 다음 세포를 포집하여 $4^{\circ} \mathrm{C}$ 에서 $12000 \times \mathrm{g}$ 으로 $5 \mathrm{~min}$ 동안 원심 분리 하였다. 이 때 생성된 pellet에 $1 \mathrm{~N} \mathrm{NaOH}$ 를 $200 \mu \mathrm{L}$ 가하고 $60^{\circ} \mathrm{C}$ 에서 $1 \mathrm{~h}$ 동안 방치한 후 microplate reader로 $405 \mathrm{~nm}$ 의 흡 광도를 측정하였다. 생성된 melanin 양은 합성 melanin을 이용 한 표준곡선으로부터 계산하였다. 총 단백질량은 bradford assay 를 통하여 구하였으며, melanin 양을 총 단백질량에 나누어 보정 하였다.

\section{B16-F10 및 CCD-1064SK 세포독성 평가}

마우스 melanoma 세포인 B16-F10 및 인간 피부에서 유래 한 섬유아세포 CCD-1064SK에 대한 솔방울 메탄올 추출물의 세포독성을 평가하였다. $10 \% \mathrm{FBS}$ 가 포함된 $\mathrm{DMEM}$ 배지에서 배양한 후, 세포를 취하여 96-well microplate에 각 well에 세 포수가 $5 \times 10^{3}$ cells/well이 되도록 $100 \mu \mathrm{L}$ 씩 분주하였다. $24 \mathrm{~h}$ 동안 $37^{\circ} \mathrm{C}, 5 \% \mathrm{CO}_{2}$ 에서 배양한 후, 배지를 제거하고, 여러 농도 의 각 시료가 포함된 새로운 배지를 넣었다. $24 \mathrm{~h}$ 배양 후, 배지 교환 없이 MTT를 PBS에 $5 \mathrm{mg} / \mathrm{mL}$ 이 되도록 녹인 용액을 각 well에 $20 \mu \mathrm{L}$ 씩 넣은 후, $3 \mathrm{~h}$ 더 배양하였다. 배지를 제거하고, 각 well에 $\mathrm{DMSO}$ 를 $100 \mu \mathrm{L}$ 씩 넣어 생성된 formazan을 녹인 후, microplate reader를 이용하여 $570 \mathrm{~nm}$ 에서 흡광도를 측정하여 세포 생존율(\%)을 계산하였고, 대조군은 kojic acid를 사용하였다.

\section{8. 통계분석}

데이터는 평균 \pm 표준편차로 표현하였으며, SPSS (Version 22.0; IBM, USA)을 사용하여 one-way analysis of variance (ANOVA) test를 실시한 후 Tukey Multiple Comparison test 로 사후검증을 실시하여 유의성을 측정하였다( $\left.{ }^{(a-c} p<.05\right)$. 또한, Student's t-test 방법에 의하여 각 구간의 유의성 차이를 검증 하였다 $\left({ }^{*} p<.05,{ }^{* *} p<.01\right)$.

\section{Results and Discussion}

\section{1. 전자공여능}

체내에 발생하는 free radical은 매우 불안정하여 급격하고 무 차별적으로 반응할 뿐만 아니라, 이러한 산화반응은 각종 질병 을 유발하며, 특히 피부 노화를 촉진시킨다. 따라서, free radical 을 안정화시키면 간접적으로 피부의 노화를 예방한다고 말할 수 있다(Hong, 2009). DPPH free radical 소거능 측정방법은 항산 화 능력을 보는데 가장 보편화된 실험방법으로 사용되고 있다. $\mathrm{DPPH}$ free radical 소거능 측정방법을 이용하여 솔방울 메탄올 추출물의 전자공여능을 측정하였으며, 대조군으로는 항산화 효 과로 널리 알려진 L-ascorbic acid을 사용하였다. 솔방울 메탄올 추출물의 $\mathrm{IC}_{50}$ 값은 $9.57 \pm 1.24 \mu \mathrm{g} / \mathrm{mL}$ 로 나타났으며, 대조군인 $\mathrm{L}$-ascorbic acid $\left(\mathrm{IC}_{50}=1.28 \pm 0.03 \mu \mathrm{g} / \mathrm{mL}\right)$ 와 비교하여 유사한 전 자공여능을 나타내었다(Table 1).

\section{2. 활성산소 소거능}

Xanthine oxidase는 purine 대사에 관여하는 비특이적 효소 로서 산화과정을 거쳐 xanthine 또는 hypoxanthine으로부터 urate를 형성한다(Duke et al,, 1973). 시험관 내에서 xanthine oxidase는 hypoxanthine을 산화기질로 ROS의 일종인 hydroxyl radical $\left(\mathrm{OH}^{-}\right)$를 발생시키고(Warner \& Wispé, 1992), 생성된 다 량의 ROS는 피부에서 색소침착이나 피부노화를 유발한다고 알 려져 있다(Chin et al., 2011). 솔방울의 활성산소 소거능을 평가 하기 위하여 NBT assay를 활용하여 항산화 활성을 측정한 결과, 솔방울 메탄올 추출물의 $\mathrm{IC}_{50}$ 값은 $3.33 \pm 0.28 \mu \mathrm{g} / \mathrm{mL}$ 로서 뛰어 난 활성산소 소거능을 보였다. 이는 항산화 효과로 널리 알려진 $\mathrm{L}$-ascorbic acid $\left(\mathrm{IC}_{50}=73.25 \pm 1.02 \mu \mathrm{g} / \mathrm{mL}\right)$ 에 비교하였을 때 매 우 강한 활성산소 소거능을 가진다고 할 수 있다(Table 1). 


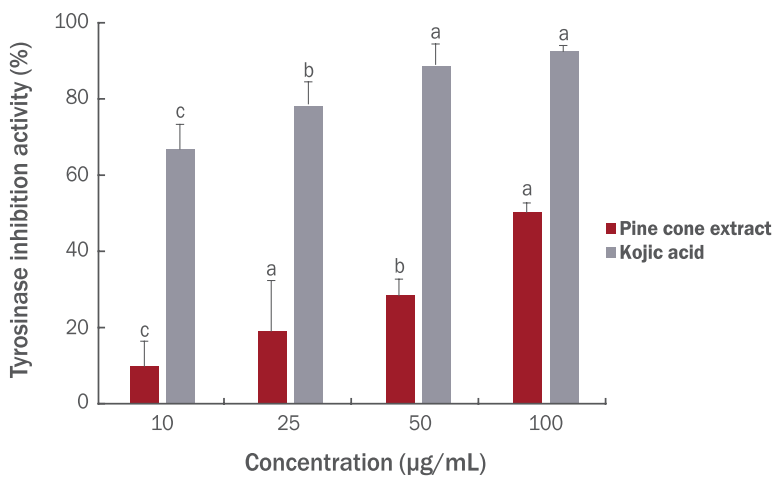

Figure 1. Inhibitory effect of pine cone extract against tyrosinase.

The pine cone methanol extract inhibited the tyrosinase activity with an $\mathrm{IC}_{50}$ value of $106.15 \pm 1.69 \mu \mathrm{g} / \mathrm{mL}$, lower effect than that of kojic acid $\left(\mathrm{IC}_{50}=3.12 \pm 0.68 \mu \mathrm{g} / \mathrm{mL}\right)$. Results designated by significance marks $\left({ }^{a-c}\right)$ were assessed by one-way ANOVA followed by Tukey Multiple Comparison test $\left({ }^{a-c} p<.05\right)$.

\section{Tyrosinase 활성 억제 효과}

미백작용이란 tyrosinase와 같은 melanin 합성 관련 효소의 활 성을 저해하여 melanin 합성을 억제하거나, 각질세포의 탈락을 도와 기존에 침착된 melanin을 옅게 하여 도움을 주는 것을 말한 다(Kim, 2006). 최근 천연물을 이용하여 피부에 친화적이고 안 정적인 미백원료를 개발하고자 하는 연구들이 활발히 진행되고 있다(Kim, 2016; Pak et al., 2016).

따라서 솔방울 메탄올 추출물의 tyrosinase 활성 억제효과를 연구하여 솔방울 추출물의 미백효능을 평가하고자 하였다. 솔 방울 메탄올 추출물의 대조군으로서는 미백효과로 많이 알려진 kojic acid를 사용하였으며, kojic acid의 $\mathrm{IC}_{50}$ 값은 $3.12 \pm 0.68 \mu \mathrm{g} /$ $\mathrm{mL}$ 로 높은 tyrosinase 활성 억제 효과를 보였다. 반면 솔방울 메 탄올 추출물의 $\mathrm{IC}_{50}$ 값은 $106.15 \pm 1.69 \mu \mathrm{g} / \mathrm{mL}$ 으로써 kojic acid보 다는 낮은 tyrosinase 활성 억제 효과를 보였다(Figure 1).

\section{Melanin 생합성 억제 효과}

마우스 melanin 형성세포인 B16-F10을 활용하여 melanin 생합 성 억제효과를 평가한 결과, 솔방울 메탄올 추출물을 $100 \mu \mathrm{g} / \mathrm{mL}$ 처리하였을 때, $36.8 \%$ 의 melanin을 저해하는 효능을 보였다. 대조 군인 kojic acid가 $100 \mu \mathrm{g} / \mathrm{mL}$ 에서 $19.3 \%$ 의 melanin 생합성 억제

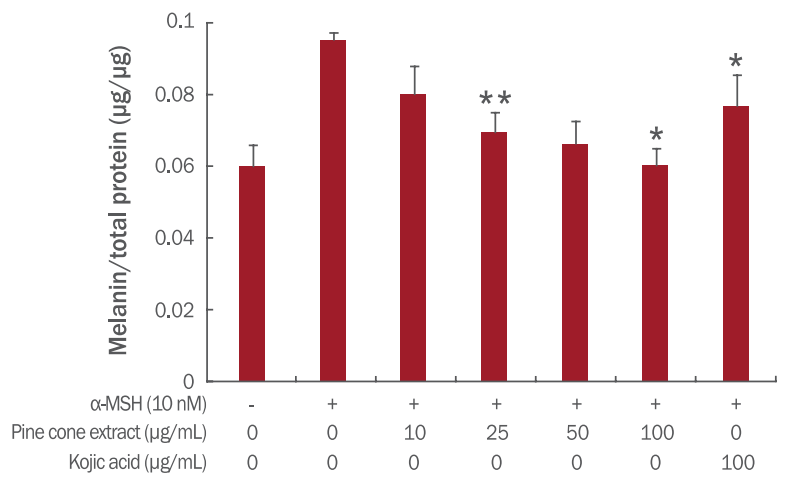

Figure 2. Inhibitory effect of pine cone extract on the melanin content of B16-F10 cells.

The inhibitory effect on melanogenesis in B16-F10 mouse melanoma cells was $36.8 \%$ at $100 \mu \mathrm{g} / \mathrm{mL}$ of the pine cone methanol extract. However, kojic acid showed 19.3\% melanin inhibition at $100 \mu \mathrm{g} / \mathrm{mL}$. ${ }^{*} p<.05$ and ${ }^{* *} p<.01$ compared with $\alpha-\mathrm{MSH}$ treated group.

효과를 보인 것에 비교해 보았을 때, 솔방울 메탄올 추출물은 매 우 높은 억제 효과를 가진 것으로 확인할 수 있었다(Figure 2). 또 한 tyrosinase 활성 억제효과와 비교하였을 때, 솔방울 메탄올 추출 물은 세포에서 그 활성이 더욱 뛰어나게 나타났다. 이는 솔방울 추 출물이 tyrosinase 활성 억제 외에 다른 기전을 통한 미백효능이 있 다고 유추할 수 있으며 추후 연구가 필요한 부분이라고 사료된다.

\section{B16-F10 및 CCD-1064SK 세포에서 솔방울 메탄올 추출 물의 세포독성 평가}

대표적인 피부세포인 마우스 melanoma B16-F10 세포 및 인간 피부에서 유래한 섬유아세포인 CCD-1064SK에서 솔방울 메탄올 추출물의 세포 독성을 평가하였다. B16-F10 세포에 시료를 가하 여 세포 독성을 측정한 결과, 대조군으로 쓰인 kojic acid는 $100 \mu$ $\mathrm{g} / \mathrm{mL}$ 에서 $88 \%$ 의 세포 생존율을 보였고, 솔방울 메탄올 추출물은 $100 \mu \mathrm{g} / \mathrm{mL}$ 에서 94.5\%로 세포 생존율을 보여 세포 독성이 없음을 확인하였다(Figure 3A). CCD-1064SK 세포에 시료를 가하여 세 포 독성을 측정해 본 결과, 솔방울 메탄올 추출물은 $100 \mu \mathrm{g} / \mathrm{mL}$ 에 서 $136.5 \%$ 로 높은 세포 생존율을 보여 세포 독성이 없음을 확인했 을 뿐 아니라, 농도가 높아질수록 일정하게 세포 생존율이 증가하 였다. 대조군으로 쓰인 kojic acid 또한 $100 \mu \mathrm{g} / \mathrm{mL}$ 에서 $119.7 \%$ 로 세포독성이 없었다(Figure 3B).

Table 1. Anti-oxidant effects of pine cone extract

\begin{tabular}{ccc}
\hline Sample & \multicolumn{2}{c}{ Radical scavenging activity $\left(\mathrm{IC}_{50}\right)$} \\
\cline { 2 - 3 } & DPPH free radical & Superoxide anion radical \\
Pine cone extract & $9.57 \pm 1.24 \mu \mathrm{g} / \mathrm{mL}$ & $3.33 \pm 0.28 \mu \mathrm{g} / \mathrm{mL}$ \\
L-ascorbic acid & $1.28 \pm 0.03 \mu \mathrm{g} / \mathrm{mL}$ & $73.25 \pm 1.02 \mu \mathrm{g} / \mathrm{mL}$ \\
\hline
\end{tabular}



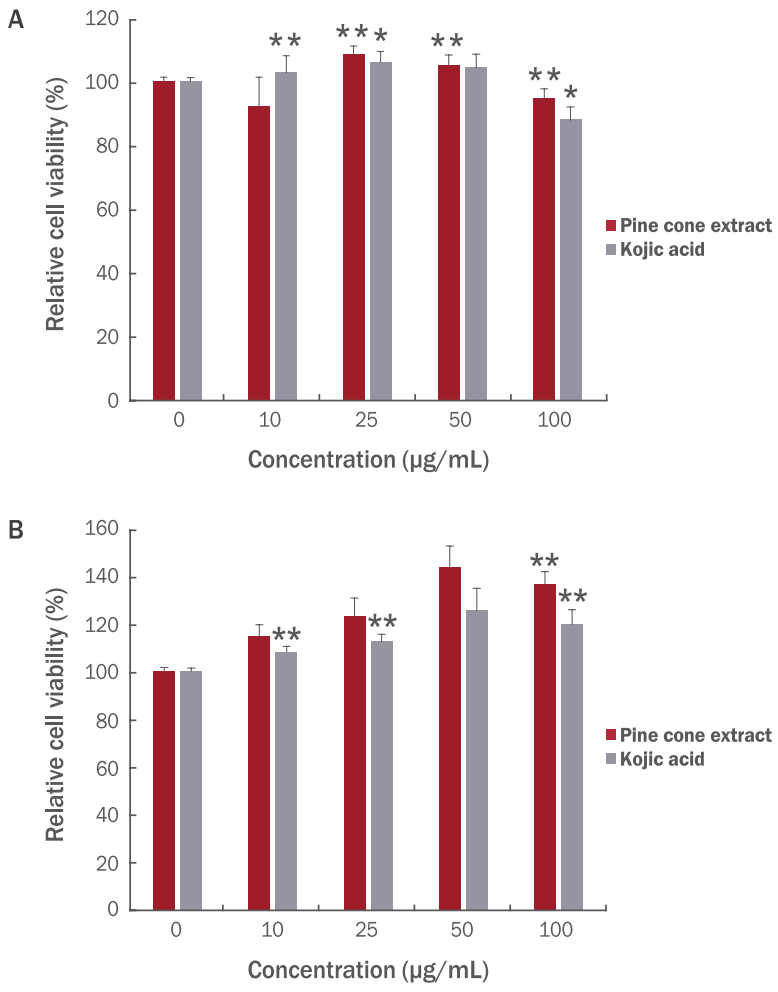

Figure 3. Cell viability of pine cone extract.

In cytotoxicity assay performed with B16-F10 mouse melanoma (A) and CCD-1064SK human fibroblast (B), the pine cone methanol extract showed $94.5 \%$ and $136.5 \%$ cell survival rate at $100 \mu \mathrm{g} / \mathrm{mL}$, respectively. Kojic acid was used as a positive control. " $p<.05$ and ${ }^{* *} p<.01$ compared with non-treated group.

\section{Conclusion}

본 연구에서는 솔방울 메탄올 추출물의 항산화 및 미백소재 로서의 가능성을 알아보기 위하여 DPPH radical 소거활성 및 NBT assay와 더 나아가 tyrosinase 저해활성, melanin 생합 성 억제 효능, B16-F10 및 CCD-1064SK 세포에서 솔방울 메 탄올 추출물의 세포독성을 평가하였다. 솔방울 메탄올 추출물 의 $\mathrm{DPPH}$ radical 소거활성 측정결과, $\mathrm{IC}_{50}$ 값은 $9.57 \pm 1.24 \mu$ $\mathrm{g} / \mathrm{mL}$ 로서 뛰어난 항산화 효과를 나타내었다. 솔방울 메탄 올 추출물의 NBT assay를 활용한 활성산소 소거능 측정결과, $\mathrm{IC}_{50}$ 값은 $3.33 \pm 0.28 \mu \mathrm{g} / \mathrm{mL}$ 로서, 항산화 효과로 널리 알려진 $\mathrm{L}$-ascorbic acid $\left(\mathrm{IC}_{50}=73.25 \pm 1.02 \mu \mathrm{g} / \mathrm{mL}\right)$ 와 비교하였을 때 매우 높은 효과를 나타내었다. Tyrosinase 활성 억제 측정결과 $\mathrm{IC}_{50}$ 값은 $106.15 \pm 1.69 \mu \mathrm{g} / \mathrm{mL}$ 로서 kojic acid보다는 낮았지만, 미백 효과는 충분히 가지는 것으로 나타났다. 솔방울 메탄올 추 출물의 melanin 생합성 억제 측정결과, $100 \mu \mathrm{g} / \mathrm{mL}$ 처리하였 을 때, $36.8 \%$ 의 melanin을 저해하는 효능을 보였다. 대조군인 kojic acid가 $100 \mu \mathrm{g} / \mathrm{mL}$ 에서 19.3\%의 melanin 생합성 억제 효 과를 보인 것에 비교해 보았을 때, 매우 높은 억제 효과를 가진 것으로 확인할 수 있었다. 마우스 melanoma 세포인 B16-F10과 인간 피부에서 유래한 섬유아세포인 CCD-1064SK에 대한 세포 독성을 측정한 결과, 솔방울 메탄올 추출물은 $100 \mu \mathrm{g} / \mathrm{mL}$ 에서 각 각 $94.5 \%, 136.5 \%$ 의 세포 생존율을 보여 세포 독성이 없음을 확 인하였다. 솔방울 메탄올 추출물은 뛰어난 항산화 효과를 가졌을 뿐만 아니라, tyrosinase 억제효과가 뛰어나 항산화 및 미백용 소 재로서의 활용가능성이 높다고 사료된다.

This work is part of the Ah Reum Lee's M.S. thesis at the Daegu haany University, Daegu, Korea.

\section{References}

Aruoma OI, Murcia A, Butler J, Halliwell B. Evaluation of the antioxidant and prooxidant actions of gallic acid and its derivatives. Journal of Agricultural and Food Chemistry, 41: 1880-1885, 1993.

Blois MS. Antioxidant determinations by the use of a stable free radical. Nature, 181: 1199-1200, 1958.

Chin EY, Han SH, Seo YM. Effect of german chamomile extract on the cell adhesion activity and melanin synthesis in cultured human skin melanoma cells damaged by xanthine oxidase/hypoxanthine. Journal of Korean Society for People, Plants and Environment, 14: 215-220, 2011.

Choi CIB, Hwang BH. Terpenoid analysis of the normal, damaged needle and pinecone in Pinus densiflora. Journal of the Korean Wood Science and Technology, 22: 72-79, 1994.

Choi YM, Jun HJ, Dawson K, Rodriguez RL, Roh MR, Jun J, Choi CH, Shim JH, Lee CH, Lee SJ, et al. Effects of the isoflavone puerarin and its glycosides on melanogenesis in B16 melanocytes. European Food Research and Technology, 231: 75-83, 2010.

Duke EJ, Joyce P, Ryan JP. Characterization of alternative molecular forms of xanthine oxidase in the mouse. The Biochemical Journal, 131: 187-190, 1973.

Hong JK. A study on skin aging caused by free-radical and on efficacy of antioxidant vitamins. Asian Journal of Beauty and Cosmetology, 7: 51-62, 2009.

Jang TW, Nam SH, Park JH. Antioxidant activity and 
inhibitory effect on oxidative DNA damage of ethyl acetate fractions extracted from cone of red pine (Pinus densiflora). Korean Journal of Plant Resources, 29: 163-170, 2016.

Kim EH. A study of whitening cosmetics from natural products. Asian Journal of Beauty and Cosmetology, 4: 195-203, 2006.

Kim HI, Oh MJ, Kim JS, Lee SC, Kwon J, Lee CH. Protective effect of fermented red ginseng extracts on photoaging skin of induced by UVB in hairless mice. Journal of Physiology \& Pathology in Korean Medicine, 29: 5865, 2015.

Kim HS. The anti-melanogenic effect of Geranium krameri extract. Korean Journal of Food Science and Technology, 48: 72-76, 2016.

Lee HB, Lee HB, Lee CY, Kim EK. Trend of depigmenting research based on patent analysis. Journal of the Society of Cosmetic Scientists of Korea, 33: 209-217, 2007.

Nerya O, Musa R, Khatib S, Tamir S, Vaya J. Chalcones as potent tyrosinase inhibitors: the effect of hydroxyl positions and numbers. Phytochemistry, 65: 13891395, 2004.
Pak WM, Kim KBWR, Kim MJ, Park JH, Bae NY, Park SH, Ahn DH. Anti-melanogenesis and anti-wrinkle effects of Sargassum micracanthum extracts. Microbiology and Biotechnology Letters, 44: 19-25, 2016.

Sakagami H, Kawazoe Y, Komatsu N, Simpson A, Nonoyama M, Konno K, Yoshida T, Kuroiwa Y, Tanuma S. Antitumor, antiviral and immunopotentiating activities of pine cone extracts: potential medicinal efficacy of natural and synthetic lignin-related materials (review). Anticancer Research, 11: 881-888, 1991.

Satoh K, Kihara T, Ida Y, Sakagami H, Koyama N, Premanathan M, Arakaki R, Nakashima H, Komatsu N, Fujimaki M, et al. Radical modulation activity of pine cone extracts of Pinus elliottii var. elliottii. Anticancer Research, 19: 357-364, 1999.

Shon MS, Kim RH, Song JH, Kwon OJ, Lee AR, Kim HO, Roh SS, Kim GN. Potential of fisetin as a nutri-cosmetics material through evaluating anti-oxidant and antiadipogenic activities. Asian Journal of Beauty and Cosmetology, 14: 6-17, 2016.

Warner BB, Wispé JR. Free radical-mediated diseases in pediatrics. Seminars in Perinatology, 16: 47-57, 1992. 


\section{국문초록}

\section{솔방울 메탄올 추출물의 항산화 및 멜라닌 생성 억제 효과}

이아름 ${ }^{1}$ 노성수 ${ }^{1}$, 이은숙 ${ }^{2}$, 민유홍 ${ }^{3 *}$

${ }^{1}$ 대구한의대학교 한의과대학, 대구, 한국

${ }^{2}$ 대구한의대학교 한방피부미용학과, 경상북도 경산시, 한국

${ }^{3}$ 대구한의대학교 뷰티케어산업학과, 경상북도 경산시, 한국

목적: 본 논문의 목적은 솔방울 메탄올 추출물의 항산화 효과 및 항멜라닌 활성을 평가하는 것이다. 방법: 솔방울 메탄올 추출물의 항산화 활성을 알아보기 위하여 2,2-Diphenyl-1-picrylhydrazyl (DPPH) 및 슈퍼옥사이드 음이온 라디칼 소거능 (superoxide anion radical scavenging activity)을 측정하였을 뿐 아니라, 미백효능을 평가하기 위하여 티로시나아제에 3,4 -Dihydroxy-L-phenylalanine (L-DOPA)를 가하여 티로시나아제 활성 저해효능을 측정하였다. 또한 멜라닌 생합성 억 제효과는 $\alpha-\mathrm{MSH}$ 를 가한 B16-F10 세포를 활용하여 확인하였고, Thiazolyl blue tetrazolium bromide (MTT)를 활용하여 세포독성을 측정하였다. 결과: 솔방울 메탄올 추출물은 높은 항산화 활성을 가지고 있고, 농도의존적으로 티로시나아제를 억 제하였을 뿐 아니라, B16-F10 세포에서 농도의존적으로 멜라닌 형성을 저해하였다. B16-F10 및 CCD-1064SK 세포에서 솔 방울 메탄올 추출물은 세포독성을 나타내지 않았다. 결론: 솔방울 메탄올 추출물은 세포독성을 나타내지 않으며 멜라닌 형성 을 저해하고 항산화 효과 또한 뛰어나므로 미백 및 항산화 소재로 충분히 활용될 수 있다고 사료된다.

핵심어: 솔방울, 메탄올 추출물, 항산화 활성, 항멜라닌 활성, 세포독성

\section{참고문헌}

김은화. 천연 추출물을 이용한 미백화장품 개발 동향에 관한 연구. 아시안뷰티화장품학술지, 4: 195-203, 2006. 김현수. 선이질풀 추출물의 멜라닌 생성 억제 효과. 한국식품과학회지, 48: 72-76, 2016. 김호일, 오미진, 김종석, 이성철, 권진, 이창현. 발효홍삼 추출물의 광노화 피부 보호 효과. 동의생리병리학회지, 29: 58-65, 2015. 박원민, 김꽃봉우리, 김민지, 박지혜, 배난영, 박선희, 안동현. 잔가시 모자반 추출물의 주름 개선 및 미백 효과. 한국미생물 - 생명 공학회지, 44: 19-25, 2016.

손명수, 김령현, 송지혜, 권오준, 이아름, 김혜옥, 노성수, 김교남. Fisetin의 항산화 및 항비만 활성 평가를 통한 미용기능식품

소재로서의 가능성 탐색. 아시안뷰티화장품학술지, $14: 6-17,2016$.

이향복, 이행병, 이처영, 김은기. 특허분석으로 본 미백 연구의 기술 동향. 대한화장품학회지, 33: 209-217, 2007.

장태원, 남수환, 박재호. 솔방울 에틸아세테이트 분획물의 항산화 및 산화적 DNA 손상 억제 활성. 한국자원식물학회지,

29: $163-170,2016$.

진은영, 한선희, 서영미. 저먼캐모마일 추출물이 Xanthine Oxidase/Hypoxanthine으로 손상된 배양 인체피부 흑색종세포의

세포부착율 및 멜라닌합성에 미치는 영향. 한국인간식물환경학회지, 14: 215-220, 2011.

최추이부, 황병호. 소나무의 정상(正常)잎, 피해(被害)잎 및 솔방울의 테르페노이드성분(成分) 분석(分析). 목재공학, 22 :

$72-79,1994$.

홍재기. 활성산소에 의한 피부노화와 항산화비타민의 효능에 대한 이론적 고찰. 아시안뷰티화장품학술지, 7: 51-62, 2009. 


\section{中文摘要}

\section{赤松松果甲醇提取物的抗氧化及抗黑色素效果}

李아름 $^{1}$, 盧盛洙 $^{1}$, 李恩淑 ${ }^{2}$, 閔惟泓 ${ }^{3 *}$

${ }^{1}$ 大邱韓醫大學校 韓醫预科, 大邱, 韩国

${ }^{2}$ 大邱韓醫大學校 韓方皮膚美容學科，慶尙北道 慶山市，韩国

${ }^{3}$ 大邱韩医大学校 産業學科, 慶尙北道 慶山市，韩国

目的：研究赤松松果甲醇提取物的抗氧化及抗黑色素效果。方法: 为了评价赤松松果甲醇提取物的抗氧化效果, 利用 2,2-Diphenyl-1-picrylhydrazyl (DPPH) 方法及超氧阴离子自由基消除能力(superoxide anion radical scavenging activity)来测定 ; 为了评价美白效能，蘑菇酪氨酸酶中加入3,4-Dihydroxy-L-phenylalanine (L-DOPA), 测定酪氨酸酶 的活性抑制效能; 添加了 $\alpha-M S H$ 的B16-F10细胞来测定黑色素抑制效果; 利用Thiazolyl blue tetrazolium bromide (MTT) 法测定细胞毒性。结果: 赤松松果甲醇提取物具有很高的抗氧化能力, 不仅抑制蘑菇酪氨酸酶, 而且在 B16-F10细胞中抑制黑色素的形成。随着赤松松果甲醇提取物的浓度的升高, 蘑菇酪氨酸酶的抑制效果和抑制黑色素 的形成也随之增加。对B16-F10 和 CCD-1064SK细胞，赤松松果甲醇提取物不具有细胞毒性。结论: 赤松松果甲醇提 取物不具有细胞毒性, 不仅抑制黑色素的形成, 而且抗氧化效果也非常明显, 因此作为美白及抗氧化原料充分具有可 行性。

关键词: 赤松松果，甲醇提取物，抗氧化活性，抗黑色素活性，细胞毒性 